\title{
Green Configuration-Based GIS Spatial Model in Riparian Area of the River Kuin Banjarmasin, Indonesia
}

\author{
Nova Annisa ${ }^{1, *}$, Hafiizh Prasetia $^{2}$, and Rony Riduan ${ }^{1}$ \\ ${ }^{1}$ Department of Environmental Engineering, Faculty of Engineering, Lambung Mangkurat University \\ ${ }^{2}$ Research Center for Chemistry, Indonesian Institute of Sciences
}

\begin{abstract}
Green cover configuration plays an important role in urban development. Research has been carried out from an investigation at riparian area of The River Kuin, Banjarmasin, Indonesia. In the riparian area of The River Kuin consists of $65.87 \%$ build-up area (red zone), $25.12 \%$ streets (gray zone), and $9 \%$ of green open space (green zone). Based on calculations with the vegetation index, the green open space which amounts to $9 \%$ is able to store carbon reserves of 129.21 tons. In addition, the presence of green open spaces also contributes to the atmosphere of life in the riparian area.
\end{abstract}

\section{Introduction}

Green open space (GOS) is a public and private facility such as a courtyard and city square for activities and sports, facilities open to the public, or those used for activities after learning activities, including playgrounds and yard city [1]. The green open space (GOS) provides a variety of benefits for local communities in urban areas, such as for recreation, habitat, and beauty, guards and improving water quality and becoming flood absorption areas, providing jobs in the agriculture, forestry and conservation sectors. Most environmental benefits of a GOS are external factors in normal market transactions and the consequences are often of no value even though the GOS clearly improves the quality of life of the community. Striving for monetary values is very important to improve individual and social welfare and for city planning, such as zoning, development, transfer of conservation land functions, ownership taxes, improvement and maintenance of existing GOS ([2]; [3]).

The structure, shape, and arrangement of GOS can be an ecological configuration and a planological configuration. GOS with ecological configuration is a landscape-based GOS such as protected areas, hills, riparian areas, lake areas, coastal areas, and others. Whereas GOS with planological configuration can be in the form of spaces formed following the pattern of urban structures such as GOS housing, GOS village, GOS sub-district, GOS city, and regional/national parks. In terms of ownership of GOS can be a public GOS that is owned by the public and open to the wider community, or private GOS in the form of parks located on private lands [4].

\footnotetext{
* Corresponding author: aiyuvasha@ulm.ac.id
} 
Green open space is a mitigation and adaptation option to climate change because of its large benefits. From an ecological point of view, green open space has a very large meaning in efforts to improve environmental quality. Pieces of green areas in urban areas have several types, such as the remnants of native ecosystems so that they are known as pieces of remnant patches, including forests or forest fragments, parts of forest land, vegetation along riparian area, road area and others, areas where natural succession processes occur without direct human intervention.

Topography Kuin Village passed by The Kuin River has an important role in connecting two major rivers in the city of Banjarmasin. But with very rapid development, the river has undergone many changes. Re-arrange management land by involving various elements of society that exists therein is a must. For this reason, it is necessary to conduct a study of the green configuration at the riparian area of the Kuin River. One way to analyze green configuration is to use a Geographic Information System (GIS). The advantage of the GIS system is that data can be accessed in real on the field, has a clear geographical point in a coordinate form and is easily overlaid with other spatial themes.

\section{Methods}

\subsection{Study Area}

This research was carried out around the riparian area of the Kuin River which is divided into two regions, namely North Kuin and South Kuin. Researchers deliberately chose The Kuin River because of the problem of very dense housing scattered along The Kuin River. The worries will get worse if the future Kuin River which has a strategic location will function as an intermediary river, thus requiring a better arrangement as the attractiveness of Banjarmasin City as a thousand river water tourism city. Specifically, the riparian area modeling plan has not even been studied so The Kuin River will become a casuistic study area and hopes that the resulting modeling can be applied elsewhere. The reasons for effectiveness and efficiency are also taken into consideration by researchers in conducting research activities on The Kuin River due to the time and financing factors.

\subsection{Research Design}

The research that will be carried out is casuistic so that the categorization of field experiment research explores the problem of green open space at the riparian area of The River Kuin Banjarmasin. Various approaches, theories, and concepts about sustainable development that are an environmentally friendly state that riparian area as a component of wetlands is still often forgotten by the community. Besides that the number of settlements in the riparian area makes the hydrological function disturbed. The absence of plants around the river will worsen the condition of the river in the city of Banjarmasin. Therefore we need a green configuration in the riparian area of The Kuin River, Banjarmasin City.

\subsection{Data Analysis}

Analysis of cover and distribution of GOS is used by analysis with Quantum GIS, to determine the building structure of green spaces and gray spaces. A number of image processing techniques are also applied to provide more optimal results, such as atmospheric correction, geometric correction, and radiometric correction. Detection of vegetation conditions in the GOS area in this study uses vegetation and visual index analysis that will 
provide information on the condition of vegetation in the riparian area and carbon content analysis in accordance with the field survey data.

\section{Results and Discussion}

\subsection{Green Configuration}

The Kuin River has a length of 3909 meters, with a width of 7-61 meters. This river passes through 8 villages, namely Antasan Kecil Timur, Sungai Miai, Pangeran, Kuin Utara, Kuin Cerucuk, Kuin Selatan, Belitung Utara, and Pasar Lama. The existence of this river is very important for water transportation activities and bathing, washing and toilet activities for the community along the river. More clearly can be seen in the following Figure (Fig. 1).

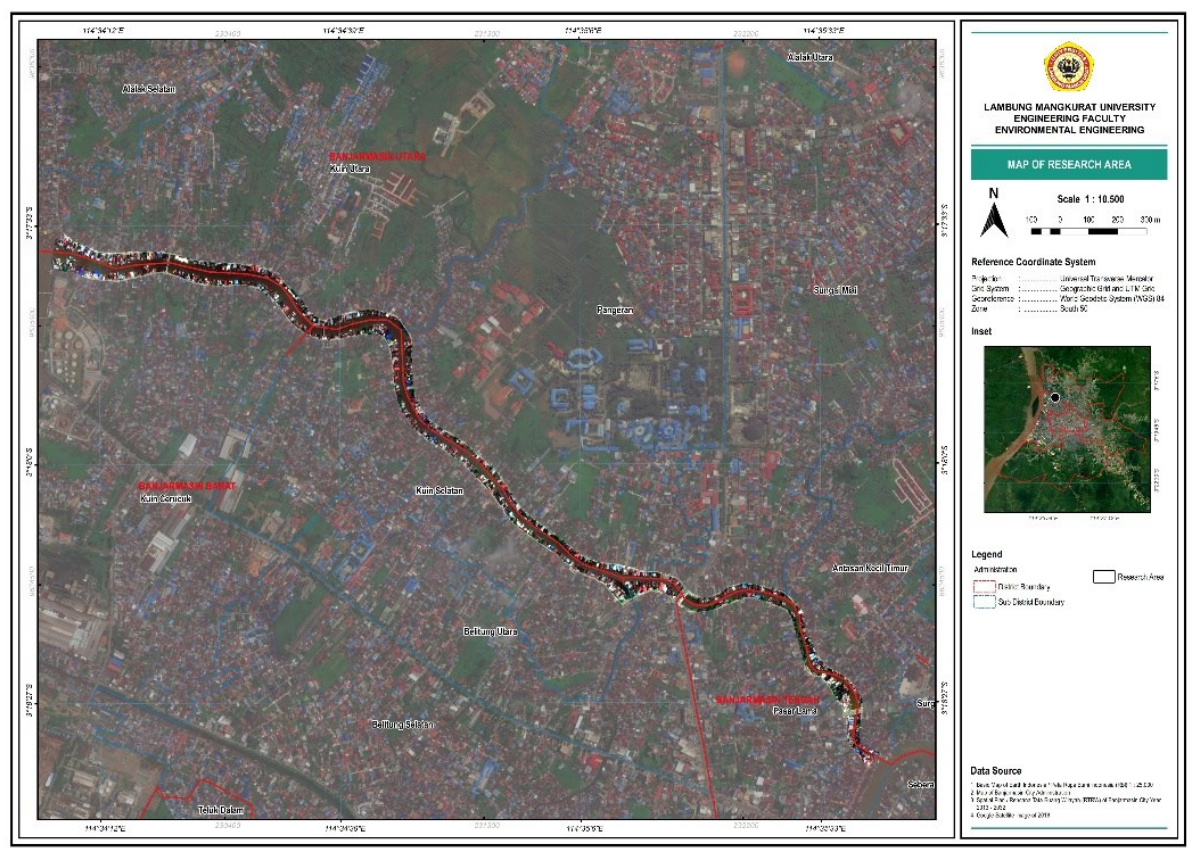

Fig. 1. Map of Research Area

Green configuration means not only the kind of vegetation composing the landscape view but also their position which finally gives values and benefits for people. In the riparian area of The River Kuin consists of $65.87 \%$ build-up area (red zone), $25.12 \%$ streets (gray zone), and $9 \%$ of green open space (green zone). See Fig. 2. The built area is six times larger than the green open space. 


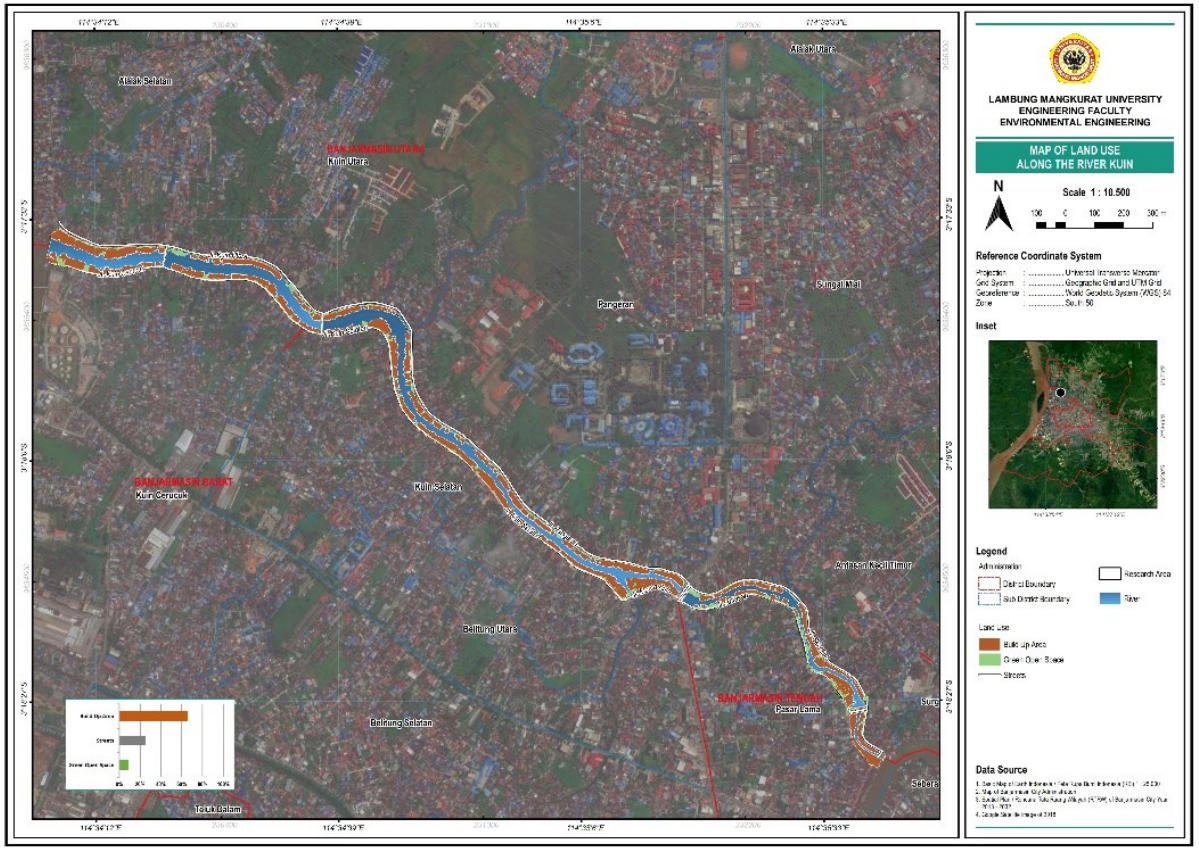

Fig. 2. Map of Land Use Along The River Kuin

The road is described as a gray zone which is the access that connects between villages in the region. From the analysis of the gray zone, the value is only $25.12 \%$, meaning that road access is very narrow for very dense areas. This can result in severe congestion in this region. The actual percentage of green, grey and build up areas as shown in the block diagram in Fig. 3 .

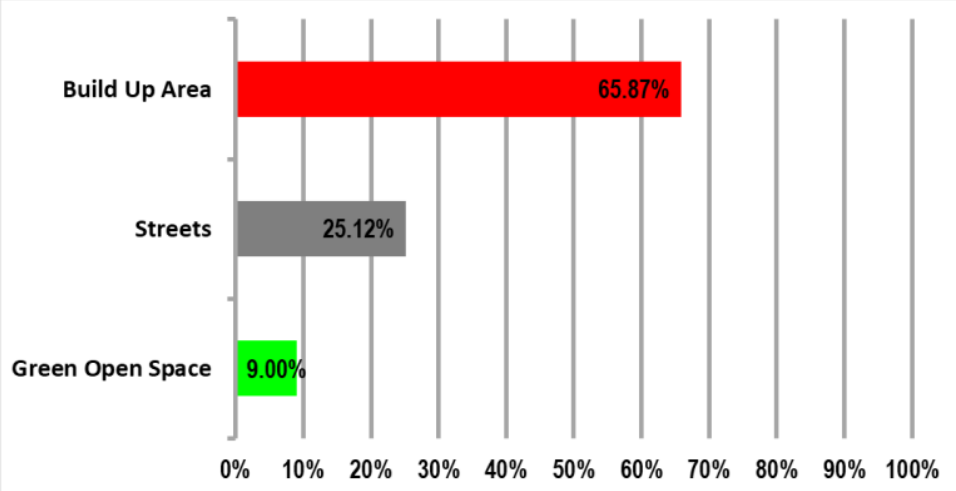

Fig. 3. The Composition of Green, Gray, and Red Zones

There two advantages can be understood from that Fig. 2 and 3, the first is there is a chance to prepare the management planning for the river development base on green open space. The second, this riparian area of The River Kuin has a high value in an urban environment due to its capability as a buffer for urban climate fluctuation. 


\subsection{Index of Vegetation and Carbon Stored}

The road is described as a gray zone which is the access that connects between villages in the region. From the analysis of the gray zone value of only $25.12 \%$, meaning that access to vegetation index is the result of the transformation of the spectral value of several channels of remote sensing images for the prominence of the spectral value of vegetation. Vegetation is one of the main parameters in GOS. The existence of vegetation in the GOS environment contributes to many things in the balance of an ecosystem. Index vegetation is the value generated from a number of remote sensing data used to measure vegetation cover on the earth's surface. Based on the vegetation index analysis (Fig. 4) in riparian area of The River Kuin there is an area of 5,093.6 square meters with very rare vegetation density and about $2,865.3$ square meters with very dense vegetation density. The road is very narrow for very dense areas. This can result in severe congestion in this region.

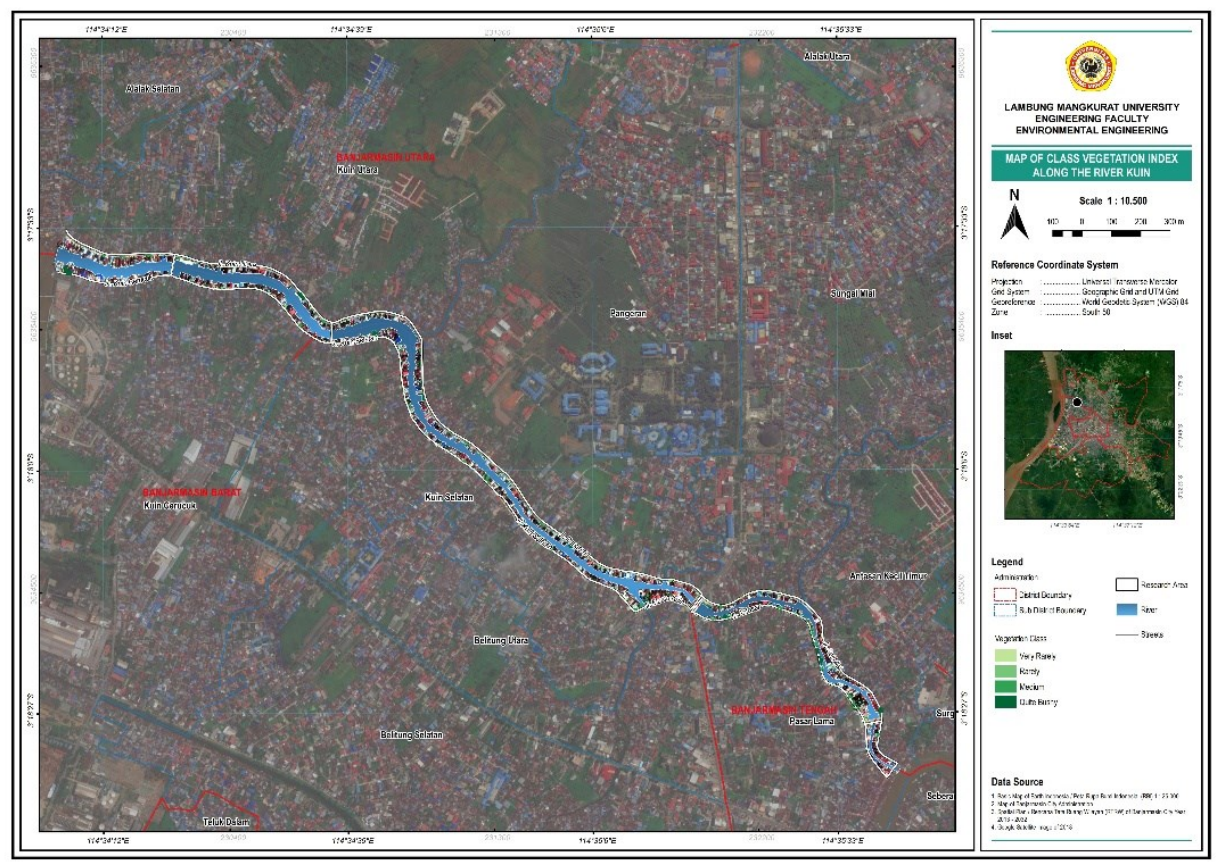

Fig. 4. Map of Class Vegetation Index Along The River Kuin

Based on spatial data processing with GIS obtained the distribution of vegetation index for all the riparian area of The River Kuin (Fig. 4), the extent and carbon stored (Table 1). Based on Table 1, carbon stored in riparian area of The River Kuin is 129.21 tons. The existence of plants as carbon stores causes the concentration of carbon dioxide in the atmosphere to decrease. Through photosynthesis, carbon dioxide is absorbed and converted by plants into organic carbon in the form of biomass. 
Table 1. Estimation of Carbon Stored on Riparian Area Of The River Kuin

\begin{tabular}{|c|l|c|c|c|c|}
\hline No & \multicolumn{1}{|c|}{ Vegetation Class } & Area $\left(\mathrm{m}^{2}\right)$ & $\begin{array}{c}\text { Carbon Stock } \\
\left(\mathrm{kg} . \mathrm{m}^{2}\right)\end{array}$ & $\begin{array}{c}\text { Total Carbon } \\
\left(\mathrm{kg} . \mathrm{m}^{2}\right)\end{array}$ & $\begin{array}{c}\text { Total Carbon } \\
(\text { ton })\end{array}$ \\
\hline 1 & Very Rarely & $5,093.60$ & 2.71 & $13,803.66$ & 13.80 \\
\hline 2 & Rarely & $1,039.20$ & 6.10 & $6,339.12$ & 6.34 \\
\hline 3 & Medium & $4,815.80$ & 10.07 & $48,495.11$ & 48.50 \\
\hline 4 & Quite Bushy & $2,865.30$ & 21.14 & $60,572.44$ & 60.57 \\
\hline \multicolumn{2}{|r|}{ Total } & $13,813.90$ & 40.02 & $129,210.32$ & 129.21 \\
\hline
\end{tabular}

\subsection{Strategy}

Riparian area has a specific and limited area, even though the demand for land in the area continues to increase and is accelerative. Development activities at riparian areas often change the natural configuration of urban landscapes. In addition, the progress of tools and the addition of transportation routes and utility systems, as part of improving the welfare of citizens, have also increased the number of pollutants and have caused various inconveniences in an area ([5]; [6]). To overcome these environmental conditions, GOS is needed as a bioengineering technique and biofilter formation which is relatively cheaper, safer, healthier and more comfortable (Fig. 5).

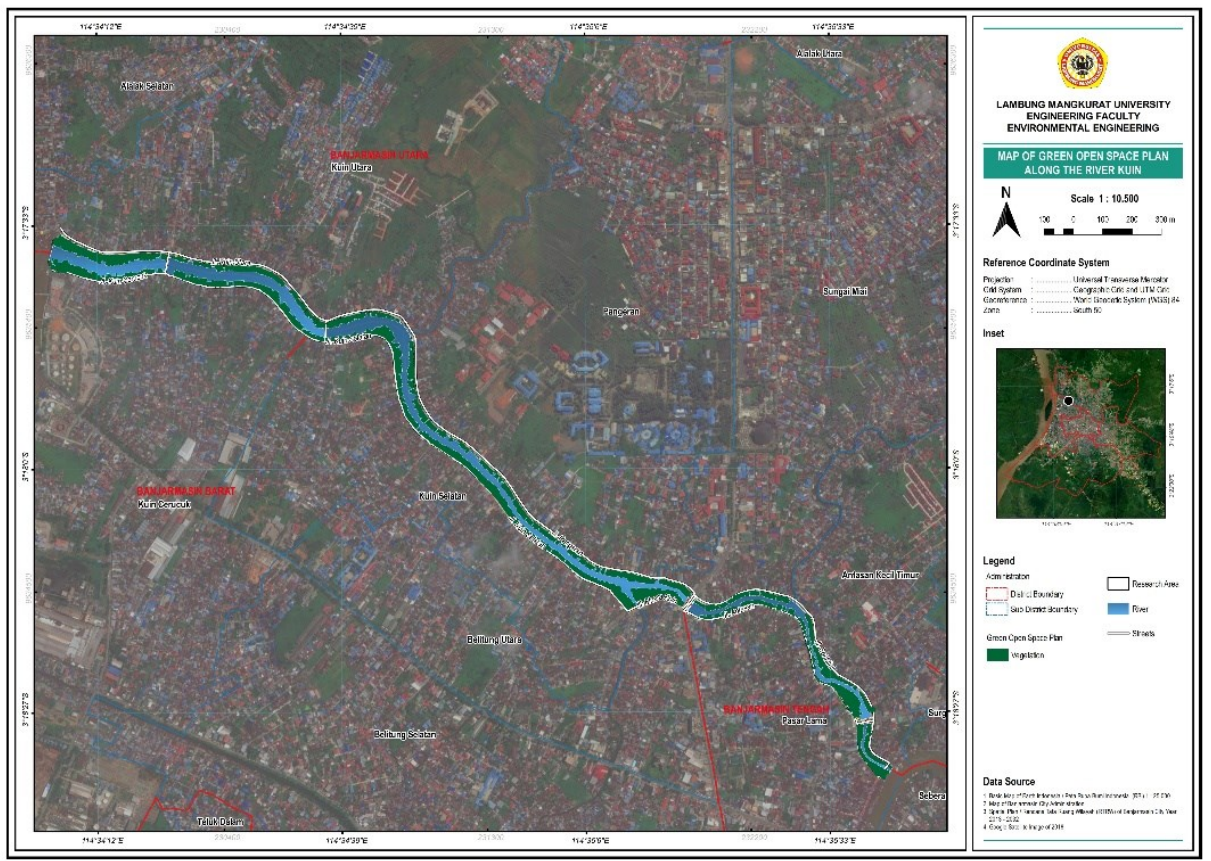

Fig. 5. Map of Green Open Space Plan Along The River Kuin

GOS riparian areas have high life benefits. Various functions (ecological, social, economic and architectural functions) and aesthetic values that they have (objects and environment) can improve quality of the environment and the continuity of life and can be a pride and identity of the city. GOS which is functional and aesthetic in a riparian area system must at least consider the minimum area, pattern and structure, as well as its form and 
distribution. Ecological characters, conditions and desires of citizens, as well as the direction and objectives of development and development of the city is the main determinants in determining the magnitude of this functional GOS [7].

Riparian area of the River Kuin has GOS in various functions with various types of vegetation. But the role of vegetation as the shade is a fundamental role for park public. After that, the criteria for convenience and ease of management are followed. This is because the temperature in the open land can reach $35^{\circ} \mathrm{C}$. While the temperature is comfortable for the body on average around $20-26^{\circ} \mathrm{C}$. This means that to reduce the temperature is needed a way to release heat, namely by evapotranspiration. By planting trees with a canopy volume of more than 80 cubic meters along riparian area, it will be cheap if used techno-biologically (soft engineering), potential evapotranspiration can be reached up to 400 liters per day, this amount is very significant to reduce air temperature. In addition, according to [8] and [9] that plants in the riparian areas are also selected based on their function as cover crops that are able to bind the soil well and prevent erosion. These plants are a combination of grasses, shrubs, and trees. The distance of trees, shrubs, and other plants are arranged in such a way so as not to interfere with each other. Empty space within the planting zone serves to provide space for the root system to grow properly ([10]; [11]; [12]; [13]; [14]).

\section{Conclusion}

Based on the description of the results and discussion, it can be concluded that the riparian area configuration is dominated by build up area (red zone) of $65.87 \%$, while the green open space area is only $9 \%$. This requires a change to prepare the management planning for the river development base on green open space. Green open space gives an opportunity to the people there for sharing atmosphere in enjoying nature. Habitat and animal refuges are two sides of one coin, the victims of urbanization. Urban animal mostly nomad and have no shelters.

\section{Acknowledgment}

This study was financially supported by The Faculty of Engineering, University of Lambung Mangkurat, Research Contract Number: 001/UN8.1.31/HP.NS/2018.

\section{References}

1. D. Fam, E. Mosley, A. Lopes, L. Mathieson, J. Morison, and G. Connellan, "Irrigation of Urban Green Spaces: a review of the Environmental, Social and Economic bene fi ts," no. 04, 2008.

2. Gayatri Acharya and L. L. Bennett, "Valuing Open Space And Land-Use Patterns In Urban Watersheds," J. Real Estate Financ. Econ., vol. 22, no. 2-3, pp. 221-237, 2001.

3. C. Germann-Chiari and K. Seeland, "Are urban green spaces optimally distributed to act as places for social integration? Results of a geographical information system (GIS) approach for urban forestry research," For. Policy Econ., vol. 6, no. 1, pp. 3-13, 2004.

4. C. Fandeli, Perhutanan Kota. Jogjakarta: Fakultas Universitas Gadjah Mada, 2004.

5. S. Scott, "Urban Green Space : the Incorporation of Environmental Values in a Decision Support System,” Development, vol. 11, no. May, pp. 177-196, 2006.

6. K. K. Dixon and K. L. Wolf, "Benefits and Risks of Urban Roadside Landscape : Finding a Livable , Balanced Response," 3rd Urban Str. Symp. Uptown, Downtown, or Small T. Des. Urban Streets That Work, pp. 1-17, 2007. 
7. K. Löfvenhaft, C. Björn, and M. Ihse, "Biotope patterns in urban areas: A conceptual model integrating biodiversity issues in spatial planning," Landsc. Urban Plan., vol. 58, no. 2-4, pp. 223-240, 2002.

8. N. Annisa, R. Riduan, and H. Prasetia, "Aplikasi Rain Garden Untuk Memperindah Dan Meningkatkan,” Jukung J. Tek. Lingkung., vol. 2, no. 2, pp. 22-37, 2016.

9. N. Annisa, "Seleksi Pohon Teduhan untuk Rain Garden," J. Tek. Lingkung., vol. 3, no. 1, pp. 30-38, 2017.

10. R. Bannerman and E. Considine, Raingardens: A How-to Manual for Homeowners. USA: Cooperative Extension Publications, 2003.

11. R. Bell et al., The Native Plant Society of New Jersey Office of Continuing Professional Education Cook College 102 Ryders Lane New Brunswick, NJ 08901-8519 Native Plants of New Jersey. New Jersey, USA: The Native Plant Society of New Jersey.

12. C. Clear and K. Giacalone, Rain Gardens. A Rain Garden Manual For South Carolina. Green Solutions To Stormwater Pollution., no. November. South Carolina: Clemson University, 2008.

13. C. Hinman, Rain Garden Handbook for Western Washington Homeowners. Designing Your Landscape to Protect Our Streams, Lake, Bays, and Wetlands. Washington: Washington State University Extension Faculty, 2007.

14. C. Hinman, Rain Garden Handbook for Western Washington. Washington: Washington State University Extension Faculty, 2013. 